\title{
Applications of sand roasting and baking in the preparation of traditional Indian snacks: nutritional and antioxidant status
}

\author{
Aruna Jyothi Kora ${ }^{1,2}$ [D
}

\begin{abstract}
Background: In India, the sand roasting technique is widely used by street food vendors, villagers and cottage industries for making various value-added food products from different cereals, millets and legumes. The traditionally produced sand-roasted products are commonly utilized as ready to eat snacks or for the preparation of various other snacks.

Results: During the high-temperature short-time treatment of sand roasting, the produced products are bestowed with characteristics such as higher puffing, crispiness, volume, and improved color, aroma, flavor and texture. In terms of nutrition, the roasting process enhances the carbohydrate and protein digestibility, $\beta$-glucan extractability, levels of dietary fiber, minerals, and antioxidants and reduces the inherent antinutrients levels in cereals and legumes. In addition, the complete destruction of seed microflora enhances the shelf life and thus consumer acceptance. The sand-roasted products act as prebiotic dietary fiber and serves as an alternative to polished grains for the consumers. Thus, the simplest, inexpensive, traditional sand roasting method of dry heat application is used for making precooked ready to eat weaning foods and preparation of cost-effective dietary pediatric and geriatric formulations. The technique is also employed for roasting various beans, fryums, nut, and pulse decortication and as a pretreatment process for tamarind kernel powder production, while the sand baking method is widely used for baking cakes, vegetables, meat, fish, eggs and starchy tubers.

Conclusions: The techniques of sand roasting and baking are gaining importance as cheap, effective, oil-free, healthier ways of cooking. However, further studies are needed on micronutrient availability and functional food development for community nutritional disorders. Also, the residual silica levels and difficult working environment mandates the development of energy-efficient and high-output-orientated technologies such as continuous, microwave, and fluidized bed roasters.
\end{abstract}

Keywords: Sand roasting, Sand baking, Antioxidant, Digestibility, Snack, Nutrition

\section{Introduction}

In terms of health benefits, minimally processed foods are better than the processed foods. Among the minimal processes, sand roasting is a traditional, rapid food processing method which utilizes dry heat for a shorter span of time. In this high-temperature short-time treatment, the heat energy is transferred via conduction. The sand roasting causes

\footnotetext{
Correspondence: koramaganti@gmail.com

${ }^{1}$ National Centre for Compositional Characterisation of Materials (NCCCM), Bhabha Atomic Research Centre (BARC), ECIL PO, Hyderabad, Telangana 500062, India

${ }^{2}$ Homi Bhabha National Institute (HBNI), Anushaktinagar, Mumbai 400094 India
}

faster dehydration, characteristic thermal and chemical reactions, and reduction in water activity of the grains. During roasting, the far infrared rays produced from the sand penetrate the grains and aid in breaking down of the starch, protein, and fats in the grains (http://www.vmosa.com/ health04_en.htm, 2019). It aids in digestibility improvement by converting the micro and macronutrients into more digestible form via rapid starch gelatinization, simultaneous drying of gelatinized starch, and denaturation of proteins. It results in higher puffing index, enhanced crispiness and volume, and improved texture. It also enhances the color, aroma, flavor, shelf life, and consumer acceptance and reduces the bulk density and antinutrients present in cereals 
and legumes (Jogihalli et al. 2017a; Sharma and Gujral 2011). The important cereals and legumes which are consumed in roasted form after sand roasting are rice, maize, sorghum, wheat, barley, oats, groundnut, black gram, bengal gram, chickpea, peas, and cowpea. The roasting depends upon on the sand temperature, temperature profile, and roasting time. They are usually roasted at a varying temperature of $150-350^{\circ} \mathrm{C}$ using sand as a heating medium, in small, medium, and industrial pan roasters in a batch mode which is practiced in villages and cottage industries of India. The roasting process affects the nutritional, antioxidant, sensory, and functional properties of the products. The demand for value-added products such as roasted cereals and grains is increasing, as it is a cheap, effective, oilfree, healthy way of cooking (Jogihalli et al. 2017a; Singh et al. 2018).

In the present review, the application of sand roasting in the production of value-added products from rice such as popped, puffed, and flaked rice; other popped and roasted cereals and millets such as barley and oats; maize, sorghum, pearl millet, and finger millet; and roasted legumes such as groundnut, chickpea, pea, cowpea is detailed. In addition, the importance of sand roasting in terms of grain characteristics, nutritional, antioxidant, sensory, and functional properties of the products is highlighted. In addition to vegetable and meat roasting, the application of sand roasting as a pretreatment process in various nut decortication is covered. The applications of sand bath in baking of cakes, vegetables, meat, fish, eggs, and starchy tubers are mentioned.

\section{Sand roasting of cereals}

The cereals belong to the family Graminaceae and include rice, wheat, maize, barley, oat, and rye. They are the important carbohydrate resources, in addition to minerals, dietary fiber, and bioactive compounds. The different methods such as conventional dry heating, sand roasting, hot-air popping, gun puffing, microwave heating are used for producing valueadded cereals with distinctive aroma and taste (Mishra et al. 2014).

\section{Sand roasting of rice}

Among the cereal crops, rice (Oryza sativa) occupies a key position as a major cereal crop and staple food in human nutrition due to its texture, taste, and nutritional qualities (Mir et al. 2016). There are vast number of paddy varieties grown in different states of India which are suited for raw milling, parboiling, and value-added rice products. In India, around 10\% of the production (14.5 million tons) is used for making value-added rice products such as popped, puffed, and flaked rice (Chitra et al. 2010).

\section{Popped rice}

It is known as pelalu, khoi, etc. in various Indian languages. It is a traditional value-added product with high cold water swelling capacity originated from raw paddy; arising from high starch gelatinization and low retrogradation (Fig. 1a). It is prepared directly by high-temperature short-time treatment from the moisture-adjusted raw paddy $(12-14 \%)$ by sand roasting in a pan at a temperature of $150-250^{\circ} \mathrm{C}$ for 25-45 s. In comparison with other value-added rice products, popped rice production is less and mostly used during religious ceremonies (Chitra et al. 2010; Murugesan and Bhattacharya 1989).

\section{Puffed rice}

It is known as maramaralu, murmura, murra, muri, puri, borugulu, mandakki, kallepuri, etc. in various Indian languages. It is one of the popular, common, oldest minimally processed food items especially used as snack, ready to eat breakfast cereal, infant food, etc. in India. It is also distributed as prasadam to devotees in temples and gurudwaras. It is mostly produced in home or cottage industries by skilled artisans using the cheaply available local material, sand as a heat transfer medium for the uniform distribution of temperature among the grains. In different regions of India, it is traditionally made from the pregelatinized, milled, parboiled rice by heating at a high temperature for a shorter time in a hot sand bath and quickly stirring in large, shallow iron or clay frying pans (Fig. 1b). The traditional fire wood burning earthen stove known as bhatti and the locally
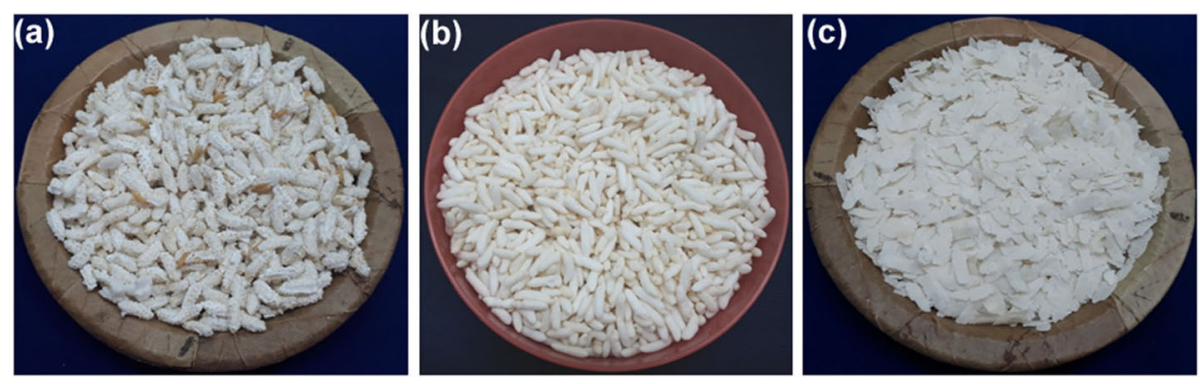

Fig. 1 Photographs of a popped rice, $\mathbf{b}$ puffed rice, and $\mathbf{c}$ flaked rice 
available, cheaper fire wood from sarkar tumma (Prosopis juliflora), wood shavings , and crop residues such as straws of cotton, chili, and agro-industrial residues, including rice husk, bagasse, groundnut shell, coconut shell, and coir pith are employed (Kumar and Prasad, 2013; Mir et al. 2016).

There are different steps involved in the puffed ricemaking process by sand roasting. First one is the selection of paddy variety that is suitable for puffing and available at a cheaper price. Generally, coarse, short, thick-grained, non-glutinous, medium amylose rice is used for puffing. The second step is the parboiling the paddy, which is done by soaking, steaming, and drying the grains. The paddy is soaked in water at room temperature for 4-5 days or in preheated water at 70 $80^{\circ} \mathrm{C}$ for $6-8 \mathrm{~h}$; water is drained and steamed at $100{ }^{\circ} \mathrm{C}$ in an open boiler or in an autoclave under pressure for 10-20 min. Then, the paddy is dried and milled. The parboiling is a hydrothermal process in which the starch granules are gelatinized and retrograded that helps in grain expansion during puffing. The milled, parboiled rice is preconditioned by soaking in salt water to obtain moisture content of $14-20 \%$ and roasted in a sand bath at $220-285^{\circ} \mathrm{C}$ for $10-25 \mathrm{~s}$ within which the grains will puff up. The grains expand nearly 8 times, become highly porous, lighter, and crispy, as a result of physical, morphological, conformational, and structural changes in the grains. The high temperature during roasting causes rapid water evaporation, creates many void spaces due to the high pressure exerted by the steam formed inside the grains, and forces the retrograded starch to expand. The puffed rice is quickly separated from the sand using a metallic strainer and cooled to room temperature. The collected puffed rice is packed in bags and marketed. The same method with variations is practiced in India for many decades and still it is continued. The critical parameters involved in the entire process are the amylose content of the parboiled rice, moisture content in the grains (10-20\%), heating medium (sand), maintenance of required puffing temperature (220$285^{\circ} \mathrm{C}$ ) and roasting time $(8-25 \mathrm{sec}$ ) (Ashwini et al. 2016; Chinnaswamy and R. Bhattacharya 2006; Kumar and Prasad, 2013; Mir et al. 2016). The puffing process differs from the popping in which controlled expansion of the kernel is done during the vapor pressure escape from the grains' micropores because of high pressure or thermal gradient (Mishra et al. 2014).

\section{Flaked rice}

It is also known as rice flakes, parched rice, flattened rice, and beaten rice in English and atukulu, avalakki, aval, poha, chura, chira, chiwada, etc. in various Indian languages. It is one of the oldest traditional rice product which is consumed as a cereal breakfast and sweet or salty snack either by toasting, roasting, frying, spicing, or soaking in water, milk, and seasoning with vegetables and spices in India. It is a flattened, carbohydrate rich, edible, precooked, rice product produced by soaking the paddy, sand roasting, and flattening (Fig. 1c). The paddy is softened by soaking in water for 2-3 days at room temperature or in warm water $\left(40-50^{\circ} \mathrm{C}\right)$ for $18-24 \mathrm{~h}$ to obtain a moisture level of $30 \%$. The water drained, soaked paddy is sand-roasted in a shallow iron pan or earthen vessel at $150-180^{\circ} \mathrm{C}$ for $28-50 \mathrm{~s}$ to reduce the moisture content. The hot paddy with a moisture content of $17-20 \%$ is flattened subsequently into flakes in an edge runner or roller flaker. The roasted grains pass repeatedly between the roller and pan edge of the edge runner, leading to the dehusking of the kernels and formation of thin, papery, white rice flakes (Chitra et al. 2010; Dutta 2014; Kumar and Prasad, 2017; Mujoo and Ali 1998).

The sand roasting method is also employed for drying high moisture paddy harvested during the monsoon. The high moisture content $(18-23 \%)$ is reduced to $5-10 \%$ by roasting in a commercial sand roaster at $95-155^{\circ} \mathrm{C}$ for $1-1.5 \mathrm{~min}$, without affecting the milling characteristics (Srinivas et al. 1981).

A study carried out on brown rice puffing indicated no loss of minerals, but a slight increase in essential trace elements such as potassium, magnesium, manganese, and phosphorous after puffing in comparison with raw rice (Mir et al. 2016). In a study on content and digestibility of starch in sand-roasted products; in comparison with raw rice, the starch content was decreased, attributed to resistant starch formation and adhering bran layers. The resistant starch formation during the sand roasting of popped rice may find applications in diabetic food preparation. While the in vitro digestibility of the popped, puffed, and flaked rice was increased when compared with raw rice, which is accounted from amylopectin structure damage. Also, the increased digestibility of the sand-roasted products suits children and elderly people with a poor state of digestibility (Chitra et al. 2010; Dutta 2014; Dutta et al. 2016). In another study on starch susceptibility to enzymatic hydrolysis; the digestibility of the flaked rice was higher when compared with raw rice, attributed to gelatinization and mechanical damage of starch during sand roasting (Mujoo and Ali 1998). Another study indicated an enhancement in protein solubility, upon sand roasting of soaked paddy at $175-250^{\circ} \mathrm{C}$ (Mujoo et al. 1998). In addition, the flaked rice is known to contain higher amounts of dietary fiber, minerals, and oryzanol than the milled raw rice. The nutritionally important, resistant starch formed in puffed and flaked rice is unaffected during digestion and absorption in the small intestine. It acts as a dietary fiber and responsible for controlling coronary heart diseases and diabetes via lowering the blood cholesterol and glycemic index, respectively. Also, it functions as prebiotic nutrient food to gut microflora, maintains the gut health and 
prevents the risk of colon cancer and other celiac diseases. In addition to serving as a low-cost, conventional, nutritious, and easily available food to masses, the gluten-free, roasted rice products are alternative to wheat products for patients suffering with celiac diseases (Kumar and Prasad, 2013; Kumar and Prasad, 2017).

\section{Sand roasting of maize}

Popcorn is the most important, popular commercial snack produced worldwide from corn (Fig. 2a). It is available in small packs, coated with various ingredients such as hydrogenated oil, sugar syrup, salt, $\beta$-carotene, favors, etc. for improving the sensory quality. There are various corn-popping methods are available including conventional sand roasting, gun popping, hot-air popping, and microwave popping. Among which, the microwave and pressure cooker popping are the most popular methods at households due to energy-efficiency and short time. The popping of maize depends on corn variety; kernel size, shape, and density; pericarp thickness; moisture content (11-16\%); popping temperature; and popping method. The large kernels expand less than the smaller, shorter. and broader kernels due to high levels of soft endosperm. During popping, the pericarps of the kernels act as pressure vessels and popping happens at respective temperature and pressure of $177^{\circ} \mathrm{C}$ and 135 psi inside the kernels. The super-heated water vaporizes, expands the starch granules into a thin film via gelatinization and generates large voids, leading to the production of popped corn. It is important to note that during popping, most of the seed microflora are destroyed and the produced popcorn is sterile (Mishra et al. 2014).

In the preparation of ready to eat foods such as corn grit, the preconditioned corn kernels with a moisture level of $20 \%$ are sand roasted at $191^{\circ} \mathrm{C}$ for $104 \mathrm{~s}$ (Kumar et al. 2018). Also, the sand-roasted corn on the cob known as bhutta is one of the most common, favorite, affordable, healthy street side snack in India, along with charcoal roasted corn on the cob. Also, it is a general practice to roast the corn kernels alone in hot sand (Kamal 2012).

\section{Sand roasting of barley}

Barley scientifically known as Hordeum vulgare is one of the ancient, important cereal crops and ranked fifth in terms of world production. The whole barley grains are roasted at $250-300{ }^{\circ} \mathrm{C}$ for $2 \mathrm{~min}$ in hot sand bath and husk is removed. The roasted grains are milled to flour known as sattu, which is widely consumed as a snack in India. It is abundant in soluble and insoluble fibers, $\beta$-glucans, phenolics, and antioxidants such as pro-anthocyanidins, flavonols, flavones, flavanones, quinines, chalcones, and benzoic and cinnamic acid derivatives. The $\beta$-glucans play an important role as soluble, dietary fiber in relieving constipation. It is also involved in the reduction of dietary cholesterol absorption and glycemic index and prevention of diet related disorders including diabetes and coronary heart diseases. It is widely used in malting, brewing, baking and the production of feed and alcohol. The abundance of antioxidants in barley aids in food preservation via lipid peroxidation inhibition (Rashid et al. 2015; Sharma and Gujral 2011; Sharma et al. 2011).

The effect of sand roasting and microwave cooking on antioxidant activity was investigated in a previous comparative study. The hulled seeds of different barley cultivars were roasted at $280{ }^{\circ} \mathrm{C}$ for $20 \mathrm{~s}$ in a traditional roaster made up of an iron pan with sand. It was reported that the sand-roasted barley showed higher antioxidant and metal chelating activities, reducing power and non-enzymatic browning in comparison with microwave cooked barley. Also, the sand-roasted barley exhibited higher retention of total phenolic and flavonoid content in comparison with microwave cooking (Sharma and Gujral 2011). The roasted barley at identical conditions showed higher water absorption, water solubility index, and oil absorption capacity which is accounted for porous structure formation in the endosperm and higher content of cooked and damaged starch (Sharma et al. 2011). In a similar study, the effect of sand roasting on antioxidant and anticancer activity of barley was
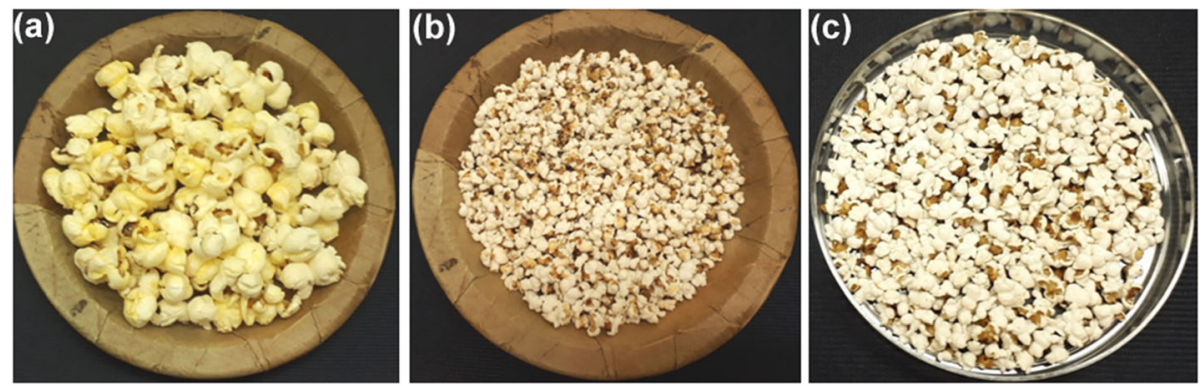

Fig. 2 Photographs of a popped maize, $\mathbf{b}$ popped sorghum, and $\mathbf{c}$ popped pearl millet 
evaluated. It was observed that the sand roasting at $280^{\circ} \mathrm{C}$ for 2 min caused considerable enhancement in 1diphenyl-2-picrylhydrazyle (DPPH) and hydroxyl radical scavenging activities, reducing power and cell proliferation inhibition, when compared with uncooked barley (Rashid et al. 2015).

\section{Sand roasting of oats and wheat}

In terms of world production, oats (Avena sativa) stand in the sixth position and it is cultivated as a fodder crop in area of 1 lakh hectares of land in India. It is recognized as a functional food due to the abundance of $\beta$ glucan, antioxidants, soluble fiber, and minerals. The phytochemical $\beta$-glucan is known to reduce the serum cholesterol and postprandial blood glucose levels. In a study carried out on ten different oat cultivars, the impact of sand roasting on $\beta$-glucan extractability and antioxidant activity was studied. The hulled oats were sand roasted in a traditional sand roaster at $280^{\circ} \mathrm{C}$ for $15 \mathrm{~s}$. It was found that the sand roasting significantly increased $\beta$-glucan availability, reducing power, DPPH radical scavenging, and metal chelating activities. The increase in $\beta$-glucan extractability is accounted to its release from the cellulose and other non-cellulosic cell wall polysaccharides of the grains by thermal effect of roasting (Gujral et al. 2011). In another study, the effect of sand roasting on various parameters of wheat (Triticum aestivum L.) was studied. The wheat was roasted at $300^{\circ} \mathrm{C}$ for $25-30 \mathrm{~s}$ by traditional method of pan roasting in sand. It was noted that sand roasting caused a considerable decrease in moisture content, bulk density, and chroma values and an increase in crispiness and porosity in comparison with the raw wheat (Murthy et al. 2008).

\section{Sand roasting of millets}

In terms of nutritional values, the millets are comparable or even better than the staple cereals such as rice and wheat. They are the cost-effective sources of protein, minerals, and vitamins for poor people. The millets are the main food and fodder crops in semi-arid regions, characterized by small grains compared to maize. However, due to antinutrient presence and poor protein and carbohydrate digestibility, processing of millets with techniques such as dry conduction heating or malting is mandatory (Choudhury et al. 2011). The whole grains of millets such as sorghum, pearl millet, and finger millet are popped by dry heating on sand baths, which is a common practice in villages (Nations 1995). The popping under high temperature for a short duration time is a process of simultaneous starch gelatinization and expansion that results in super-heated vapor production inside the grains, sudden endosperm expansion and breaking out of outer skin (Mishra et al. 2014).
The popped sorghum is a ready to eat snack, produced traditionally in a batch process by manual sand roasting in cottage industries and villages of India. It is produced from the grains with a moisture content of $16-80 \%$ by sand roasting in a wide-mouth concave pan at $240{ }^{\circ} \mathrm{C}$ for $1 \mathrm{~min}$ by continuously agitating with iron ladle (Fig. 2b). The popped grains expand nearly 8 times and are separated from the sand with a perforated pan. As it is produced from the whole grains, it is bestowed with all the nutrients of native sorghum (Benhur et al. 2016; Nations 1995). The high popping yield and greater volume expansion of millets depend upon the variety, grain characteristics such as size, weight, bulk density, hardness, moisture, protein and amylose content, endosperm type, and popping method (Mishra et al. 2014). When compared to boiling, popping is an energy-efficient and nutritionally desirable process. It utilizes less fuel and marginally hydrolyses the proteins and vitamins, in addition to improvement in flavor. In Central India, it is mostly consumed by school going children as a snack and drinks, derived from the pounded, popped sorghum flour. The popped sorghum is used in weaning food formulations and in the form of flour and laddu during festivals (Mishra et al. 2014). The whole, sorghum seed heads known as panicles harvested during the dough stage are roasted in hot sand and thus obtained soft, sweet seeds are used as a snack. These sugary endosperm varieties with $30 \%$ glycogen are found in the Maharashtra state of India (Council; et al. 1996).

In a study carried out on pearl millet (Pennisetum glaucum), the effect of sand roasting on physical characterstics, texural properties, and sensory attributes in making sattu was studied (Fig. 2c). Sattu in drink form is considered as the best breakfast food during summer seasons due to its cooling effect and good digestibility. It is prepared from the roasted cereals, legumes, or combination of both with added flavoring agents. It was found that the sand roasting at $180^{\circ} \mathrm{C}$ for $1 \mathrm{~min}$ is optimal for making sattu (Mridula et al. 2008). For the finger millet (Elusine coracana), the optimal popping conditions were found to be $19 \%$ moisture and sand roasting at $270{ }^{\circ} \mathrm{C}$ (Malleshi and Desikachar 1981). In addition to finger millet, the other minor millets such as foxtail millet, barnyard millet and proso millets were popped with roasting and highest popping yield and expansion volume was obtained with proso millet (Srivastava and Batra 1998). In another study carried out on minor millets including foxtail millet, barnyard millet, kodo millet, proso millet, and little millet; the highest popping and expansion ratios were obtained with kodo millet followed by little millet (Mishra et al. 2014).

In a study carried out on carbohydrate and protein digestibility of foxtail millet (Setaria italica), the two processing techniques such as sand roasting and malting 
were compared. The grains with $10 \%$ moisture popped by sand roasted at $230^{\circ} \mathrm{C}$ for $15 \mathrm{~s}$ showed higher carbohydrate and protein digestibility in comparison with malted and raw grains. It is attributed to starch granule release form protein matrix and reduced antinutrients leading to enhanced amenability to enzymatic digestion. Thus, the sand-roasted millets could be utilized in the preparation of cost-effective, dietary formulations for children and geriatrics (Choudhury et al. 2011).

\section{Sand roasting of legumes}

The seeds of various leguminous plants such as groundnut, chickpea, pea, cowpea, red gram, and soybean are sand roasted for the preparation of snacks and other value-added food products in India.

\section{Sand roasting of groundnut fruits and seed kernels}

The groundnut (Arachis hypogea) seeds are the plant source of carbohydrates, dietary protein, essential minerals, vitamins, and healthy fats in sufficient quantities. It is ranked at third position in abundantly cultivated oilseeds in the world. In India, it is grown in the rain-fed areas of Gujarat, Andhra Pradesh, and Tamil Nadu states (Nirmale et al. 2017). Traditionally, the fruits and seed kernels are roasted in small, open-sand bath pan roasters (Fig. 3a). The roasting is critical in determining the flavor, texture, and nutritional values of the kernels. The sand roasting is one of the oldest cooking techniques used by the street side food vendors and villagers of India for obtaining crunchy, crispy, crackling, and roasted peanuts (www.myKottayam.com 2017). For the purpose of roasting groundnut fruits and seed kernels, a clay pot specially designed for sand roasting known as mangalam is used in the villages of Andhra Pradesh state. It is made from an old or unused or leaky clay pot in which a hole is made on one side to insert a wooden ladle for mixing during roasting (Fig. 3b) (Wikipedia 2019). The dry roasted peanuts provide sufficient quantities of mono-unsaturated fatty acids in diet and reduce low density lipoprotein cholesterol level in the blood, there by prevents the chance of coronary artery diseases (Fig. 3c). Also, dry roasting reduces the aflatoxin levels in the groundnuts. Further, roasting releases polyphenols such as p-coumaric acid and hydroxybenzoic acid, known antioxidants which limit the carcinogenic nitrosamine formation in stomach and decrease stomach cancer risk (Chikelu et al. 2015).

Many food industries use the roasted peanuts for making various food products, which mandates the use of peanut processing machines for peeling. For effective peeling, the peanuts should be sand roasted and the sand temperature is kept in the range of $150-160^{\circ} \mathrm{C}$ for $45-60 \mathrm{~s}$ (Nirmale et al. 2017). In the preparation of chikki, which is a jaggery-based, sweet snack; the groundnuts which are low in fat levels and less prone to rancidity upon storage are selected. For this, the kernels are medium roasted in a sand bath at $120-125^{\circ} \mathrm{C}$ and used during the sweet preparation (Manay and M. 2008). The vitamin E is an important micronutrient derived from the plant oils and acts as an antioxidant, prevents essential fatty acids oxidation in the body, and fights against coronary heart diseases and cancer. The vegetable oil derived from groundnut is a rich source of vitamin E. In an earlier report, the
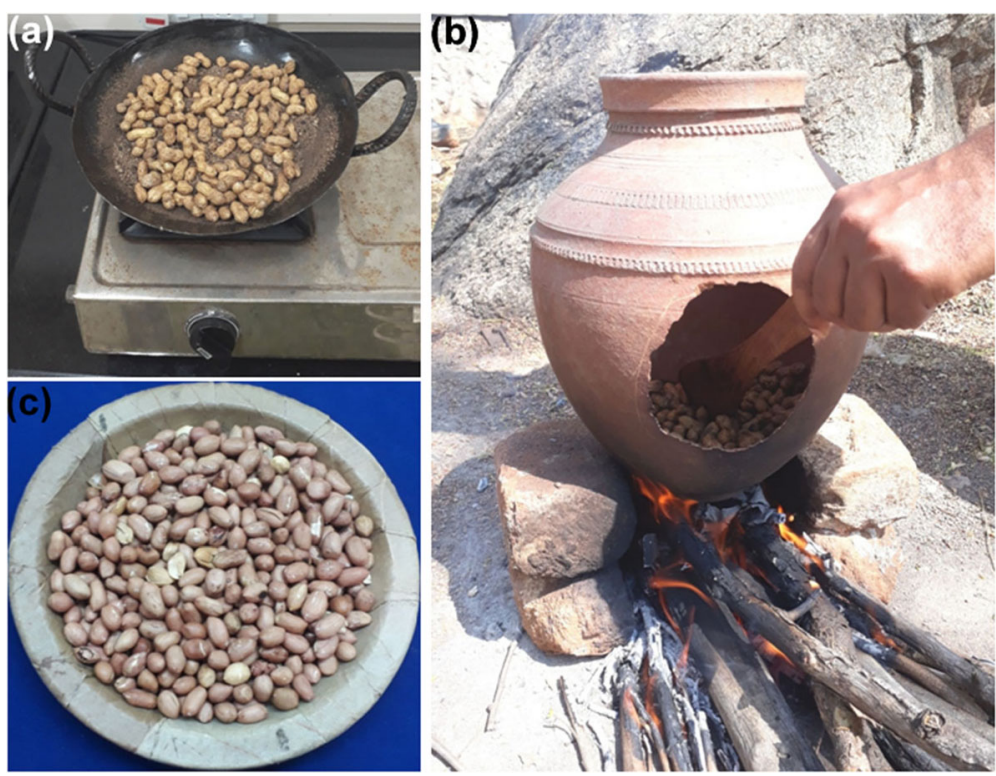

Fig. 3 Photographs of sand roasting of peanut fruits in $\mathbf{a}$ an open iron pan; $\mathbf{b}$ a traditional, designed pot mangalam; and $\mathbf{c}$ sand-roasted peanuts 
vitamin E content of groundnut which was traditionally sand roasted in an open aluminum pot for 30 min was studied. It was found that the vitamin $\mathrm{E}$ level was higher in the roasted groundnuts than in the raw groundnuts (Ejoh and Ketiku 2013).

\section{Sand roasting of chickpea, cowpea, pea, black gram, and kidney beans}

The chickpea (Cicer arietinum) is one of the main legume crops in Indian sub-continent and stands as an important resource for proteins and carbohydrates. In terms of protein quality, it is superior to other legumes such as red, black, and green gram. The seeds are classified as desi (Indian origin) and kabuli (Mediterranean and Middle Eastern origin) types based on seed color and geographic distribution (Kaur et al. 2005).

In India, the roasted chickpea is a popular, traditional snack consumed daily due the abundance of carbohydrates, proteins, essential amino acids, minerals, and dietary fiber (Fig. 4a). It is used for the preparation of sattu (roasted grain powder), fortified extruded foods, drinks, sweets, etc. (Fig. 4b). For the development of value-added products, the chickpeas are roasted at $150-350^{\circ} \mathrm{C}$ using conduction, convection, and radiation modes of heat. In a contemporary study, the effect of sand roasting on physico-functional and antioxidant properties of chickpea was evaluated. The optimally sand-roasted chickpea grains at $180^{\circ} \mathrm{C}$ for $5 \mathrm{~min}$ showed an increase in the surface area and a decrease in the bulk density. Also, the sand roasting caused an increase in water and oil absorption capacities and water absorption index. In the process of roasting, the grains are exposed to higher temperature for a shorter duration of time during which the imbibed water is transformed to vapor. The generated steam within the compact grain structure causes grain puffing, leading to void generation in the cellular matrix, starchy endosperm expansion, and enhancement in surface area. Subsequently, the increase in volume and faster removal of moisture causes a decrease in the bulk density of the roasted grains. The sand roasting at a moderate temperature exhibited an increment in total phenolic content and DPPH activity, attributed to heat-induced, extractable phenolic release and formation of Maillard reaction products that occurs only above a temperature of $120^{\circ} \mathrm{C}$. It is worth noting that the sand roasting also bestows texture, flavor, and aroma to the grains as a result of starch gelatinization; formation of desirable acid aromatic compounds, esters and alkenes during Maillard reaction; increment in levels of nitro compounds, melanoidins, biogenic amines, and lipid peroxidation products; and alteration in the composition of olefins, lipids, and alkenes (Jogihalli et al. 2017a; Jogihalli et al. 2017b). It was found that among the desi and kabuli varieties sand roasted at $190^{\circ} \mathrm{C}$ for 5 min, the desi variety PDG-3 was suitable for roasting. It is due to its highest puffing capacity, puffing index, least breaking strength, and percent hard-shelled grains (Kaur et al. 2005).

In another recent study on chickpea, the optimum sand roasting was recorded at $220^{\circ} \mathrm{C}$ for $10 \mathrm{~min}$ for obtaining higher puffing index, lower hardness, and rupture energy (Singh et al. 2018). In a different study, the antioxidant properties of chickpea seeds sand roasted at $280^{\circ} \mathrm{C}$ for $25 \mathrm{~s}$ were compared with raw seeds. The roasting treatment augmented the total phenolic content, reducing power, metal chelating, and antioxidant activities (Gujral et al. 2013). In another work, the nutritional quality of the chickpea seeds roasted on a sand bath at $180^{\circ} \mathrm{C}$ for $20 \mathrm{~min}$ was compared with pressure cooked and raw seeds. The sand roasting treatment retained most of the minerals including sodium, potassium, magnesium, iron, and phosphorous; amino acids especially lysine, leucine, valine, cysteine, and tyrosine; and polyphenols present in the raw seeds when compared with pressure cooking (Daur et al. 2008). In an earlier reported case on chickpea and black gram (Vigna mungo), the sand roasting treatment at $220^{\circ} \mathrm{C}$ for $5 \mathrm{~min}$ did not show significant change in the fatty acid composition of the extracted oils (Liaquat et al. 2008).

The occurrence of antinutrients in legume seeds limits their applications as food and feed, even though they are the basic sources of proteins, minerals, and vitamins. The antinutritional factors include tannins, phytic acid, trypsin inhibitors, and flatulence causing oligosaccharides. The tannins limit the digestibility of proteins and carbohydrates by the inhibition of digestive enzymes.
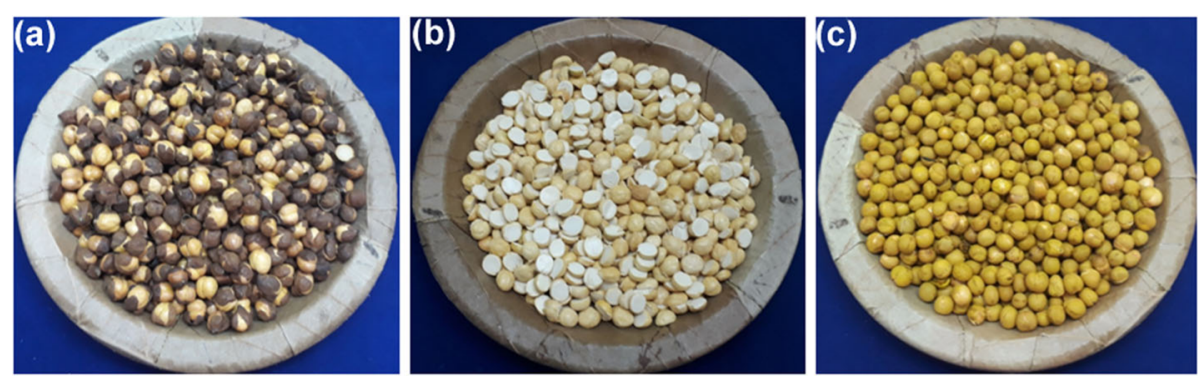

Fig. 4 Photographs of a sand-roasted chickpeas; $\mathbf{b}$ spitted, dehusked sand-roasted chickpeas; and $\mathbf{c}$ sand-roasted peas 
The phytic acid decreases the bioavailability of essential dietary minerals, proteins, and starch in humans by binding to them. On the other hand, the trypsin inhibitors reduce the digestion and absorption of dietary proteins by severe inhibition of the enzyme trypsin. In a previous study carried out on the effect of physical treatments on nutritional quality of legume seeds, the concentration of antinutrients was investigated. The cowpea (Vigna sinensis L.), pea (Pisum sativum L.), and kidney beans (Phaseolus vulgaris L.) were roasted in a sand bath at $180^{\circ} \mathrm{C}$ for 15 and $20 \mathrm{~min}$, respectively (Fig. 4c). The applied sand roasting caused significant decrease in tannin, phytic acid, trypsin inhibitor, and oligosaccharide content in comparison with the raw seeds. Especially, the sand roasting completely removed the of trypsin inhibitors (Khattab and Arntfield 2009). The essential amino acid content was also increased after sand roasting as compared with raw seeds (Khattab et al. 2009). In another study on cowpea, the sand roasting was found to be superior in comparison with microwaving in terms of puffing and sensory results (Kamble 2017). In addition, the sand roasting technique is also employed for roasting peas, bengal gram, black gram, and soybean.

\section{Sand roasting of other food items}

The low carbohydrate sun flower kernels which are abundant in unsaturated fatty acids, proteins, minerals, and vitamins are also sand roasted for obtaining tasty, aromatic, crunchy, and crispy-textured snacks (Mosayebi et al. 2018). Also, the chestnuts and coffee beans are sand roasted for the characteristic aroma (DeAangelis, 2015). The technique is also used for oil-free roasting of starchbased fryums known as vadiyalu and appadalu made up of rice and black gram flour, respectively (Fig. 5a).

The sand roasting is also employed for making anardana. In Himachal Pradesh state of India, the anardana production is a household activity. It is prepared from the seeds of wild, culled, or highly acidic pomegranate fruit varieties by sand roasting for easier separation of tightly adhered seeds. The dehydrated seeds are acidic, abundant in vitamin $\mathrm{C}$ and minerals, and extensively used in culinary preparations as a substitute for tamarind and mango slices; for garnishing ice cream, chutney, fruit salad, and pan masala; and preparation of digestive and other ayurvedic medicines (Parashar et al. 2009).

\section{Other applications of sand roasting}

The sand roasting is one of the simplest, convenient, and oldest industrial techniques employed for seed coat removal from tamarind seeds. The seeds are roasted in hot sand bath at $100-250{ }^{\circ} \mathrm{C}$ for $2-3 \mathrm{~min}$ for loosening the testa from the seed kernel. The loosened seed coat is removed by rubbing in a decorticator followed by aspiration and separation (Fig. 5b-d). The kernels rich in starch are pulverized into tamarind kernel powder (TKP), a value-added product. The roasting temperature and time determines the subsequent steps such as dehulling and grinding of the kernels and the color of the ground kernel powder. The TKP is extensively used as a sizing, binding, film forming, coating, conditioning, gelling, thickening, stabilizing, bulking, dehydrating, glazing, drug delivery agent, adhesive, emulsifier, disperser, and food additive in textile, jute, plywood, paper, leather, printing, food, and pharmaceutical industries (Bharadwaj et al. 2007; Bhattacharya 2014; Thombare et al. 2014).

Generally, the processing of nutmeg nuts into kernels is a tedious, time-consuming, and drudgery operation. It involves decortication, separation, and grading due to the lack of efficient mechanical equipment. Hence, various preshelling treatments which affect the physical and mechanical properties of nutmeg nuts before decortication was investigated. The sand roasting at $60^{\circ} \mathrm{C}$ for $20 \mathrm{~min}$ is used as a pretreatment method before the decortication of nutmeg nuts (Said et al. 2013). The sand medium is also used for decortication of the cashew nuts (Anacardium occidentale L.) and roasting of the kernels (Emelike and Ebere 2015). In comparison with cold, water, and steam treatments which are imposed for softening the shells; the sand roasting of Cuddapah almond (Buchanania axillaris) fruits at $60^{\circ} \mathrm{C}$ for 20 min gave a higher kernel recovery by the decorticator. It is also employed as preconditioning process for aiding in subsequent decortication of various pulses (Jadhav Vinayak, 2010).
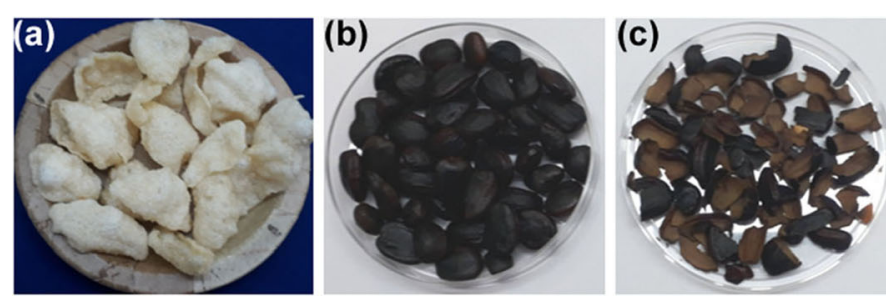

(d)

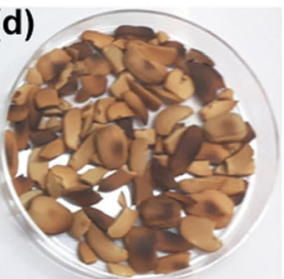

Fig. 5 Photographs of a sand-roasted fryums, vadiyalu and $\mathbf{b}$ sand-roasted tamarind seeds, c separated seed testam and $\mathbf{d}$ decorticated seed kernels 


\section{Sand baking of vegetables, eggs, meat, and cake} Sand baking is a method of slow cooking during which the food is exposed to dry heat for longer times, employing sand as the heat transfer medium. During baking, the heat is steadily transferred from the surface to the center results in formation of baked food with dry crust and a soft center. It is used as one of the slow cooking methods for meat and vegetables in coastal areas such as Goa, where the sea sand is abundant. The marinated vegetables or meal wrapped in aluminum foil and covered with flat dough, resembling a chapati are placed in a pan or tray filled with sand and slow cooked. The baking time varies based on the type of food, i.e., 30, 40, and $120 \mathrm{~min}$ for vegetables, fish, and meat, respectively. This slow cooking method prevents the ingredients from burning, retains the flavor, and, devoid of oil or less use of oil, makes it a tasty and healthier cooking. It is practiced as a fun group activity for family members and friends during camp nights. In villages, it is common to bake meat and fish wrapped and tied in banana leaf in hot sand. Also, it is a traditional practice to bake the clay-wrapped eggs in hot sand by the agricultural labor in fields. Similarly, starchy tubers such as potatoes, sweet potatoes, taro, tapioca, and yams are also sand baked. Sometimes corn ears are also baked in hot sand for 5-6 h (Das 2017; Nair 2018). The cake baking with hot sand is an age-old, traditional practice in many countries and now also it is considered as a viable alternative to microwave baking (Fig. 6).

\section{Conclusions}

The sand roasting technique is used extensively in India by street food vendors, villagers, and cottage industries for the production of various ready to eat food products from different cereals, millets, and legumes. The process not only enhances the sensory characteristics of the products such as aroma, texture, crispiness, volume, etc. but also improves the nutritional and antioxidant values.
They include reduction in antinutritional factors, destruction of seed microflora, enhancement in carbohydrate and protein digestibility; $\beta$-glucan extractability, dietary fiber, vitamin E, minerals, shelf life, consumer acceptance, and antioxidant levels. In terms of value-added health products, the sand-roasted products act as prebiotic dietary fiber and serves as an alternative to polished or refined grains for the consumers. Thus, the simplest, inexpensive, traditional sand roasting method of dry heat application is employed for making precooked ready to eat weaning foods and preparation of cost-effective dietary formulations for children and geriatrics. The technique is also used for roasting beans, fryums, and as a pretreatment process for commercial production of TKP and decortication of nuts and pulses. Also, the sand baking method is widely used for baking cakes, vegetables, meat, fish, eggs, and starchy tubers. However, further studies are needed on micronutrient availability and development of functional foods for community nutritional disorders.

The limitations of the sand roasting technique are lack of temperature control, uneven temperature distribution and sand contamination in the final products (Sharma and Gujral 2011). The sand roasting method is energy inefficient, tedious, manual in operation involving continuous hand stirring, sometimes unhygienic, and limited by low output. The workers are prone to direct influence of heat, flame, and smoke originated from the commonly used fuels such as crop and agro-industrial residues, wood, charcoal, kerosene, and gas (Chikelu et al. 2015; Murthy et al. 2008). Thus, the current traditional and industrial sand roasting method necessitates the development an alternate technology for production of value-added cereal and legume food products which is low-cost, energyefficient, effective, high-output-orientated with no exposure of the food products to impurities. For example, continuous, microwave, and fluidized bed roasters save cost, reduces the manual labor, enhances productivity, and

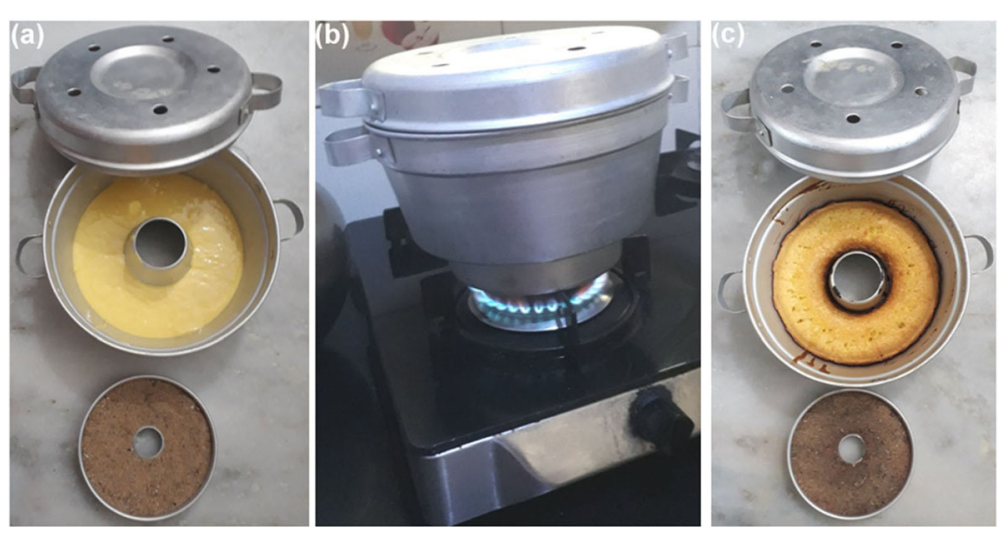

Fig. 6 Photographs of common, household baking vessel a before, $\mathbf{b}$ during, and $\mathbf{c}$ after sand baking of the cake 
maintains uniformity in roasted products. In addition to consumer satisfaction, it also provides temperature range optimization, even heat distribution within the heating chamber and food grains and applicability to wide range of materials (Jogihalli et al. 2017a).

\section{Acknowledgement}

The author would like to thank Dr. Athyala Christian Sahayam, Head, Bulk Analysis Section (BAS), and Dr. Sunil Jai Kumar, Head, NCCCM/BARC, for their constant encouragement and support throughout the study.

\section{Authors' contributions}

The author alone was involved in data collection, compilation, writing, and interpretation during the manuscript preparation. The author read and approved the final manuscript.

\section{Funding}

No funding source to declare.

\section{Availability of data and materials}

Not applicable

\section{Ethics approval and consent to participate}

Not applicable

\section{Consent for publication}

Not applicable

\section{Competing interests}

The author declares that she has no competing interests.

Received: 1 August 2019 Accepted: 21 September 2019 Published online: 21 November 2019

\section{References}

Ashwini MV, Robinson P, Madhu G, Syed S (2016) Design and fabrication of domestic puffed rice making machine International Journal of Engineering Research \& Technology, vol 5, pp 428-432

Benhur DR, Malleshi NG, Annor GA, Patil JV (2016) Value Chain: Processing interventions. In: Millets value chain for nutritional security: a replicable success model from India. CABI Publishing:98-100

Bharadwaj S, Mahorkar VK, Panchbhai DM, Jogdande ND (2007) Preparation of tamarind kernel powder for value addition Agriculture Science Digest, vol 27, pp 194-197

Bhattacharya S (2014) In: Bhattacharya S (ed) Roasting and toasting operations in food: process engineering and applications. Conventional and Advanced Food Processing Technologies, pp 221-248. https://doi.org/10.1002/ 9781118406281.ch10

Chikelu CC, Chikelu UMU, Onyekwere DC, Ekwereike GC, Okpanachi AI (2015) Design of a groundnut kernel roastmaster International Research Journal of Engineering and Technology, vol 02, pp 17-24

Chinnaswamy R, R Bhattacharya K (2006) Studies on expanded rice. Physicochemical basis of varietal -differences Journal of Food Science 48: 1600-1603 doi:https://doi.org/10.1111/j.1365-2621.1983.tb05041.x

Chitra M, Singh V, Ali SZ (2010) Effect of processing paddy on digestibility of rice starch by in vitro studies. Journal of Food Science and Technology 47:414-419. https://doi.org/10.1007/s13197-010-0068-3

Choudhury M, Das P, Baroova B (2011) Nutritional evaluation of popped and malted indigenous millet of Assam. Journal of Food Science and Technology 48:706-711

Council NR, Affairs; PaG, Development; BoSaTfl, Affairs Ool (1996) Sorghum: specialty types. In: Lost Crops of Africa Volume I: Grains, vol https://www.nap. edu/read/2305/chapter/13\#178. 1st edition edn. The National Academies Press, Washington, DC, pp 177-178. doi:https://doi.org/10.17226/2305.

Das K (2017) Mumbai Food: Chef Rahul Kulkarni reveals his cheat sheet for sand roasting. Mid-Day Infomedia Ltd. Accessed 04th January 2019 Sep 17, 2017

Daur I, Ahmad I, Jahangir M (2008) Nutritional quality of roasted and pressurecooked chickpea compared to raw (Cicer arietinum L.) seeds vol 24.

DeAangelis M (2015) Entrepreneur returns home to create A.C. coffee blend vol https://www.pressofatlanticcity.com/business/entrepreneur-returns-home-to- create-a-c-coffee-blend/article_4ba1 ebfe-c39c-11e4-b733-cfdf8d9ec387.html. The Press of Atlantic City, Pleasantville, NJ

Dutta H (2014) Study on the effects of parboiling on rice and rice products of Assam. Tezpur University

Dutta H, Mahanta CL, Singh V, Das BB, Rahman N (2016) Physical, physicochemical and nutritional characteristics of Bhoja chaul, a traditional ready-to-eat dry heat parboiled rice product processed by an improvised soaking technique. Food Chemistry 191:152-162. https://doi.org/10.1016/j. foodchem.2014.10.144

Ejoh SI, Ketiku OA (2013) Vitamin E content of traditionally processed products of two commonly consumed oilseeds - Groundnut (Arachis Hypogea) and Melon seed (Citullus Vulgaris) in Nigeria. Journal of Nutrition \& Food Sciences 3:187

Emelike NJT, Ebere CO (2015) Influence of processing methods on the tannin content and quality characteristics of cashew by-products. Agriculture and Food Sciences Research 2:56-61

Gujral HS, Sharma P, Rachna S (2011) Effect of sand roasting on beta glucan extractability, physicochemical and antioxidant properties of oats LWT - Food Science and Technology 44:2223-2230. https://doi.org/10.1016/j.lwt.2011.06.001

Gujral HS, Sharma P, Sharma R (2013) Antioxidant properties of sand roasted and steam cooked Bengal gram (Cicer arietinum) Food Science and Biotechnology 22:183-188 doi:https://doi.org/10.1007/s10068-013-0065-1

http://www.vmosa.com/health04_en.htm (2019) Far infrared ray (F.I.R.). Accessed 31st January 2019

Jadhav Vinayak S (2010) Development of proto-type for decortication of Cuddapah almond (Buchanania axillaris (Desr.) T. P. Ramamoorthy). University of Agricultural Sciences, Bangalore

Jogihalli P, Singh L, Kumar K, Sharanagat VS (2017a) Novel continuous roasting of chickpea (Cicer arietinum): Study on physico-functional, antioxidant and roasting characteristics LWT 86:456-464. https://doi.org/10.1016/j.lwt.2017.08.029

Jogihalli P, Singh L, Kumar K, Sharanagat VS (2017b) Physico-functional and antioxidant properties of sand-roasted chickpea (Cicer arietinum). Food Chemistry 237:1124-1132. https://doi.org/10.1016/j.foodchem.2017.06.069

Kamal FS (2012) Treats from the street: delicious and affordable. The Express Tribune News Network. Accessed 31st January 2019

Kamble PS (2017) Studies on process standardization and quality assessment of cowpea (Vigna Unguiculata L. Walp) puffed snacks. Vasantrao Naik Marathwada Krishi Vidyapeeth, Parbhani

Kaur M, Singh N, Sodhi NS (2005) Physicochemical, cooking, textural and roasting characteristics of chickpea (Cicer arietinum L.) cultivars. Journal of Food Engineering 69:511-517. https://doi.org/10.1016/j.jfoodeng.2004.09.002

Khattab RY, Arntfield SD (2009) Nutritional quality of legume seeds as affected by some physical treatments 2. Antinutritional factors LWT - Food Science and Technology 42:1113-1118. https://doi.org/10.1016/j.lwt.2009.02.004

Khattab RY, Arntfield SD, Nyachoti CM (2009) Nutritional quality of legume seeds as affected by some physical treatments, Part 1: protein quality evaluation LWT - Food Science and Technology 42:1107-1112 doi:https://doi.org/10.1016/.lWt.2009.02.008

Kumar S, Kumar A, Kumar S, Kumar A (2018) Process optimization for the development of ready to eat corn grits Journal of Pharmacognosy and Phytochemistry SP1:816-819

Kumar S, Prasad K (2013) Effect of paddy parboiling and rice puffing on physical, optical and aerodynamic characteristics International. Journal of Agriculture and Food Science Technology 4:765-770

Kumar S, Prasad K (2017) Optimization of flaked rice dry roasting in common salt and studies on associated changes in chemical, nutritional, optical, physical, rheological and textural attributes Asian. Journal of Chemistry 29:1380-1392

Liaquat L, Hamid S, Khan JI (2008) Effect of microwave and sand roasting on physicochemical values and fatty acids of Cicer arietinum (white gram) and Vigna mungo (black gram) oils. Pakistan Journal of Scientific and Industrial Research 51:15-18

Malleshi NG, HSR D (1981) Varietal differences in puffing quality of ragi (Eleusine coracana). Journal of Food Science and Technology 18:30-31

Manay NS, M. S (2008) Sugar \& confectionery. In: Foods : Facts And Principles. New Age International Pvt Ltd Publishers, pp 424-425

Mir SA, Bosco SJD, Shah MA, Mir MM (2016) Effect of puffing on physical and antioxidant properties of brown rice Food Chemistry 191:139-146 doi:https:// doi.org/10.1016/j.foodchem.2014.11.025

Mishra G, Joshi DC, Panda BK (2014) Popping and puffing of cereal grains: a review Journal of Grain Processing and Storage, vol 1, pp 34-46

Mosayebi M, Kashaninejad M, Najafian L 2018, Optimizing physiochemical and sensory properties of infrared-hot air roasted sunflower kernels using response surface methodology Journal of Food Quality Volume 2018 :14 
Mridula D, Goyal RK, Manikantan MR (2008) Effect of roasting on texture, colour and acceptability of Pearl Millet (Pennisetum glaucum) for making Sattu. International Journal of Agricultural Research 3:61-68

Mujoo R, Ali SZ (1998) Susceptibility of starch to in vitro enzyme hydrolysis in rice, rice flakes and intermediary products LWT. Food Science and Technology 31:114-121. https://doi.org/10.1006/fstl.1997.0300

Mujoo R, Chandrashekar A, Zakiuddin Ali S (1998) Rice protein aggregation during the flaking process Journal of Cereal Science. J CEREAL SCI 28: 187-195. https://doi.org/10.1006/jcrs.1998.0199

Murthy KV, Ravi R, Bhat KK, KSMS R (2008) Studies on roasting of wheat using fluidized bed roaster. Journal of Food Engineering 89:336-342. https://doi. org/10.1016/j.jfoodeng.2008.05.014

Murugesan G, Bhattacharya KR (1989) The nature of starch in popped rice Carbohydrate Polymers 10:215-225 doi:https://doi.org/10.1016/01448617(89)90013-1

Nair S (2018) This is why your street shakarkandi tastes yum vol 2019. http:// timesofindia.indiatimes.com/articleshow/63453435.cms?utm_source= contentofinterest\&utm_medium=text\&utm_campaign=cppst, Times Internet

Nations FaAOotU (1995) Nutritional quality of foods prepared from sorghum and millets. In: Sorghum and Millets in Human Nutrition. Agricultural and Consumer Protection of the Food and Agricultural Organisation, Rome, p 190

Nirmale VM, Khade DP, Jamdagni RU, Nalwade SV, Adadande AS (2017) Design and development of peanut peeling machine International. Journal for Reasearch and Development in Technology 7:11-15

Parashar A, Gupta SK, Kumar A (2009) Studies on separation techniques of pomegranate seeds and their effect on quality of Anardana African. Journal of Biochemistry Research 3:340-343

Rashid U, Gani A, Shah A, Ahmad M, Baba WN, Masoodi FA (2015) Effect of sand roasting on the antioxidant and antiproliferative activity of barley (Hordeum vulgare) Nutrafoods 14:227-236 doi:https://doi.org/10.1007/s13749-015-0054-5

Said PP, Pradhan RC, Kumar A (2013) Effect of pre-shelling treatments on nutmeg seed physical properties. Seed Technology 35:137-143

Sharma P, Gujral HS (2011) Effect of sand roasting and microwave cooking on antioxidant activity of barley. Food Research International 44:235-240. https://doi.org/10.1016/j.foodres.2010.10.030

Sharma P, Gujral HS, Rosell CM (2011) Effects of roasting on barley $\beta$-glucan, thermal, textural and pasting properties. Journal of Cereal Science - J CEREAL SCI 53:25-30. https://doi.org/10.1016/j.jcs.2010.08.005

Singh SV, Jogihalli P, Singh L, Kumar K (2018) Effect of roasting method on physico-mechanical and roasting characteristics of chickpea (Cicer arietinum). Journal of Agricultural Engineering 55:36-46

Srinivas T, Bhashyam MK, Shankara R, Vasudeva S, HSR D (1981) Drying-cumcuring of freshly harvested high moisture paddy by roasting with hot sand. Journal of Food Science and Technology 18:184-187

Srivastava S, Batra A (1998) Popping qualities of minor millets and their relationship with grain physical properties. Journal of Food Science and Technology -Mysore 35:265-267

Thombare N, Srivastava S, Chowdhury AR (2014) Multipurpose applications of tamarind seeds and kernel powder Science Reporter September:32-33

Wikipedia (2019) Urumu urimi mangalam meeda padinatlu.

www.myKottayam.com (2017) Selling sand-roasted peanuts for 60 years! Accessed 04th January 2018

\section{Publisher's Note}

Springer Nature remains neutral with regard to jurisdictional claims in published maps and institutional affiliations.

\section{Submit your manuscript to a SpringerOpen ${ }^{\circ}$ journal and benefit from:}

- Convenient online submission

- Rigorous peer review

- Open access: articles freely available online

- High visibility within the field

- Retaining the copyright to your article

Submit your next manuscript at $\boldsymbol{\nabla}$ springeropen.com 